Jurnal Geografi, Edukasi dan Lingkungan (JGEL) Vol. 4, No. 2, Juli 2020: 68-75

P-ISSN: 2579-8499; E-ISSN: 2579-8510

Doi: https://doi.org/10.22236/jgel.v4i2.5119

Website: http://journal.uhamka.ac.id/index.php/jgel

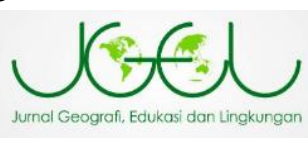

\title{
Penggunaan Metode Multiple Ring Buffer Untuk Pemodelan Spasial Area Terdampak Ledakan Jaringan Pipa Minyak Dan Gas Di Kecamatan Kedokanbunder Kabupaten Indramayu
}

\author{
Reza R.D. Junyar*, Lili Somantri, dan Iwan Setiawan \\ Program Studi Pendidikan Geografi Departemen Pendidikan Geografi \\ Fakultas Pendidikan Ilmu Pengetahuan Sosial, Universitas Pendidikan Indonesia, \\ Bandung, Indonesia \\ *E-mail: rezajunyar@upi.edu \\ Received: 4062020 / Accepted: 16062020 / Published online: 25072020
}

\begin{abstract}
ABSTRAK
Banyaknya instalasi jaringan pipa minyak dan gas bawah tanah di Indonesia memiliki potensi bencana gagal teknologi yaitu potensi ledakan sesuai dengan tingkat risikonya. Untuk itu, tujuan artikel ini mengkaji pemodelan spasial area terdampak ledakan jaringan pipa minyak dan gas di Kecamatan Kedokanbunder Kabupaten Indramayu. Pada penelitian ini digunakan metode analisis Multiple Ring Buffer sebagai analisis spasial. Teknik yang digunakan untuk memodelkan besaran dan luasan area pemukiman terdampak terhadap potensi ledakan pipa, dengan membuat peta sebaran wilyah terdampak potensi ledakan dengan memperhatikan besaran elemen risiko terkait kerugian. Dari proses analisis dilakukan zonasi pada wilayah terdampak yang diatributkan berdasarkan pewarnaan. Hasil menunjukkan daerah zona berwarna merah terdapat empat desa yang masuk dalam radius 100 meter dari pipa gas, yaitu Desa Jayawinangun, Desa Kedokan Agung, Desa Kedokanbunder, dan Desa Kedokan Wetan. Sedangkan untuk pemukiman yang masuk dalam wilayah zona warna kuning dan warna hijau radius 300 dan 500 meter dari pipa gas terdapat lima desa, yaitu Desa Jayawinangun, Desa Cangkingan, Kedokanagung, Desa Kedokanbunder, dan Desa Kedokanwetan. Selanjutnya tingkatan eskalasi untuk potensi ledakan dijadikan acuan untuk menentukan radius dan zonasi area terdampak yaitu berat, sedang, dan rendah.
\end{abstract}

Kata Kunci: Sistem Informasi Geografis, Multiple Ring Buffer, Ledakan, Pemukiman, Zonasi.

\section{ABSTRACT}

The large number of underground oil and gas pipes in Indonesia and other countries will certainly have the impact of a disaster that continues to lurk, namely the explosion of the pipe. This study aim to analysis spatial modeling of the area affected by the explosion of oil and gas pipelines in Kedokanbunder District, Indramayu Regency. This study uses spatial analysis techniques using GIS by utilizing the buffer method. This will show how much the settlement was affected by the pipe explosion so that it can be mapped, both from the side of the area and the side of the damage. From the results of the analysis that has been done, there are four villages included in the red zone settlement (100 meter radius of the gas pipeline), namely Jayawinangun, Kedokan 
Agung, Kedokanbunder, and Kedokan Wetan. As for the yellow and green zone settlements (300 and 500 meters from the gas pipeline) there are five villages, namely Jayawinangun, Cangkingan, Kedokanagung, Kedokanbunder, and Kedokanwetan. In the future, the use of explosion levels based on the standard reference can be used to determine the severe, moderate and low radius and zone so that the results will be even better.ditulis di bawah abstrak dalam format bold, dan isi kata kunci merupakan substansi dari manuskrip.

Keywords: Geographic Information Systems, Multiple Ring Buffer, Explosion, Settlement, Zoning.

\section{PENDAHULUAN}

Sistem Informasi Geografis (SIG) merupakan sebuah sistem yang didesain untuk menangkap, menyimpan, memanipulasi, menganalisa, mengatur, dan menampilkan seluruh jenis data geografis (Irwansyah, 2013). Pengaplikasian teknologi SIG ini tentu menjadi sangat dibutuhkan mengingat penggunaannya lebih praktis, efisien, dan dapat pula menghemat biaya serta hasilnya cenderung lebih cepat dan baik.

Didalam SIG, data dibedakan menjadi dua jenis, yaitu data spasial (keruangan) dan data nonspasial (atribut). Data spasial adalah data mengenai tata ruang (menyangkut titik koordinat). Data spasial terbagi atas 2 representasi yaitu representasi data raster dan data vektor. Model data raster adalah model data yang berupa image. Model data raster akan disimpan dalam bentuk grid, dimana setiap grid mewakili data tertentu. Model data vektor adalah model data yang didefinisikan dalam suatu bentuk garis, poligon, titik dan sejenisnya (Wijaya, Wahyutomo, \& Suprayogi, 2016).

$$
\text { Penggunaan SIG sering }
$$

dimanfaatkan dalam pemetaan daerah rawan bencana seperti pemetaan bencana banjir. Salah satu metode atau pendekatan yaitu partisipational mapping yang selanjutnya diinterpolasikan serta dilakukan proses scoring dan overlay dalam SIG (Dahlia, Rosyidin, \& Nurbudiansah, 2017).
Kabupaten Indramayu memiliki benyak kilang minyak aktif, salah dua nya adalah Balongan dan Mundu, sehingga pengangkutannya yaitu menggunakan media pipa minyak dan gas bawah tanah yang menjalar dibawah tanah Indramayu, termasuk di Kecamatan Kedokanbunder (Utami \& Sedjati, 2014).

Gagal teknologi didominasi oleh adanya kebakaran, ledakan serta kegagalan dalam sistem produksi seperti terbakarnya boyler, korsleting pada trafo, hingga bocornya reaktor. Selain itu kejadian sabotase, jebolnya bendungan dan segala hal teknis yang terjadi berhubungan dan berdampak terhadap lingkungan dan alam disebabkan adanya proses kegagalan dalam rangkaian teknologi yang sering terjadi di sektor industri (Rosyidin, Sribrotopuspito, Sunarto, Pambudi, Dahlia, \& Wisesa, 2016). Di Indonesia, kasus ledakan pipa pernah terjadi di unit amonia PT Petrokimia Gresik Jawa Timur pada tahun 2006. Kecelakaan tersebut dapat disebabkan karena pelaksanaan analisis risiko yang kurang serta faktor kegagalan pada pipa yang tidak teridentifikasi (Pradana \& Dwiyanti, 2013).

Manfaat yang didapat dengan menggabungkan data gambar (peta) dengan data-data tabulasi (angka dan teks), memungkinkan SIG menganalisis dan memodelkan mengenai bentukan fenomena yang ingin didapat sebagai informasi perencanaan. Salah satu faktor yang dapat diukkur adalah fenomena- 
fenomena yang dapat diolah aplikasi teknik buffer atau buffering (Aqli, 2010).

Buffering juga berfungsi untuk membentuk data spasial baru berupa poligon atau zona dengan jarak tertentu dari data spasial yang menjadi masukannya. Data spasial titik menghasilkan data spasial baru berupa lingkaran yang mengelilingi titik tersebut, sedangkan data spasial garis akan menghasilkan data spasial baru berupa poligon yang mengelilingi garis tersebut (Andreva, 2010). Dengan menggunakan analisis Buffer ini, peneliti bermaksud membuat analisis sederhana terhadap pemukiman yang mungkin terdampak atau mengalami kerusakan apabila terdapat ledakan pipa minyak dan gas, khusunya di wilayah Kecamatan Kedokanbunder.

\section{METODE PENELITIAN \\ Waktu dan Lokasi Penelitian}

Penelitian ini dilakukan pada rentang waktu Bulan April sampai Mei 2020. Wilayah penelitian dilaksanakan di Kecamatan Kedokanbunder, Kabupaten Indramayu. Adapun lokasi penelitian terdapat dalam peta Gambar 1 .

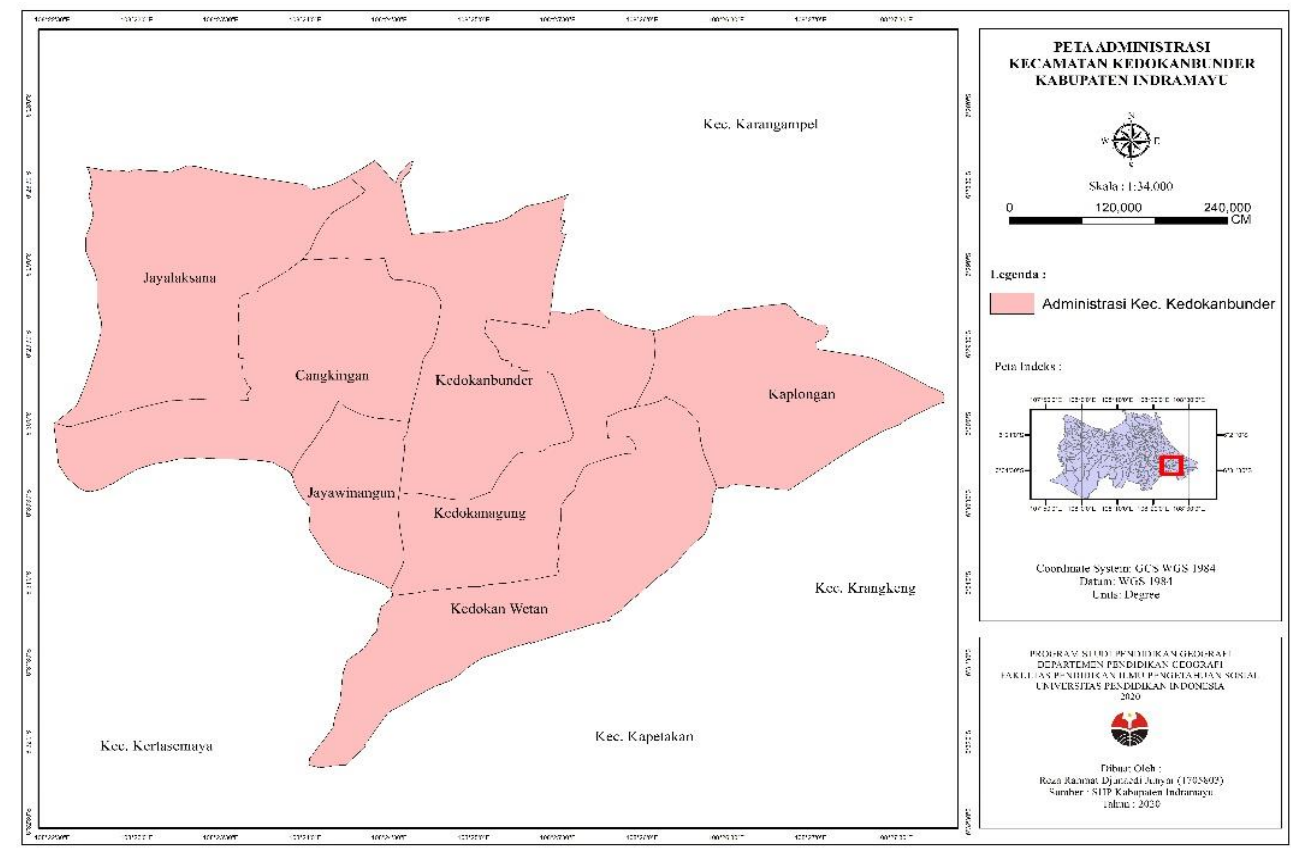

Gambar 1. Peta Lokasi Penelitian

\section{Alat dan Bahan}

Dalam penelitian ini, alat dan bahan yang digunakan yaitu:

1. Alat Penunjang Kegiatan
a. Laptop Asus X441S Intel
b. Dual-Core N3060 Up to 2.48
c. GHz, RAM 2GB, 64-bit Operating System

2. Perangkat lunak penunjang
a. Software ArcMap 10.5
b. Data SHP Kabupaten Indramayu

\section{Jenis Penelitian}

Penelitian yang dilakukan yaitu berupa penelitian kuantitatif karena menghasilkan sesuatu yang terukur yaitu dengan melakukan analisis menggunakan aplikasi ArcMap 10.5 dan memanfaatkan metode Buffer. Terkait analsisi spasial menggunakan metode buffer kajian sebelumnya mengkaji terkait wilayah rentan penyakin demam berdarah (Syamsir \& Daramussseng, 2018). 
Pemetaan Lokasi wisata Agro (Adil, 2016).

Metode pengumpulan, pengolahan, dan Analisis Data

Pada penelitian ini, data yang digunakan adalah data sekunder, yaitu menggunakan fungsi Multiple Ring Buffer. Proses analisis dilakukan dengan menggunakan bantuan alat Multiple Ring Buffer yang tersedia pada aplikasi ArcMap 10.5. Hasil analisis berupa peta sebaran pemukiman terdampak ledakan pipa minyak dan gas di Kecamatan Kedokanbunder Kabupaten Indramayu. Proses analisis disajikan pada alur penelitian (Gambar 2).

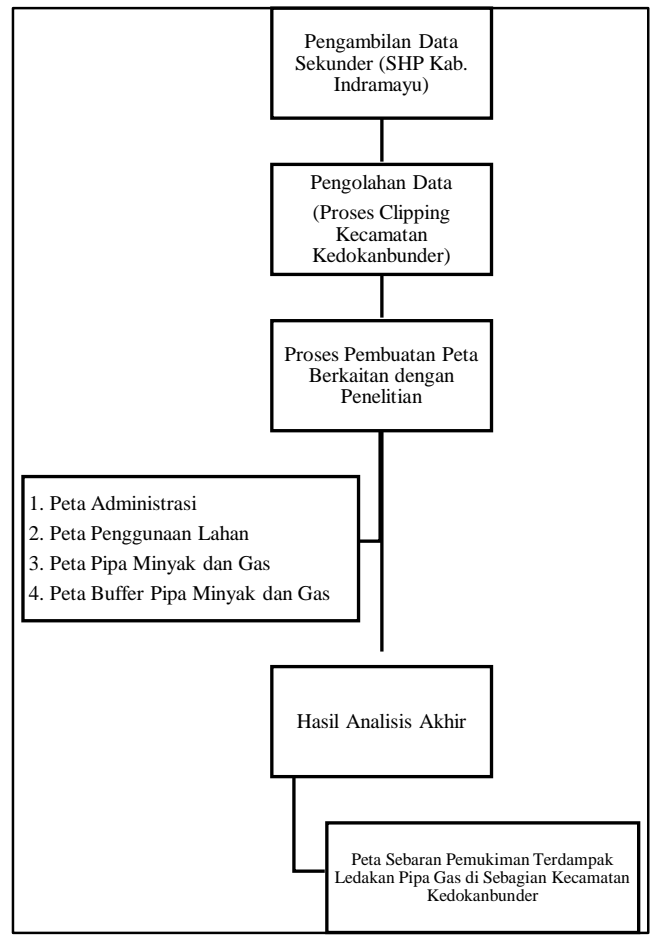

Gambar 2. Diagram alir penelitian

\section{HASIL DAN PEMBAHASAN Analisis Penggunaan Kecamatan Kedokanbunder}

Kecamatan Kedokanbunder Kabupaten Indramayu didominasi oleh penggunaan lahan untuk persawahan dengan penggunaan lahan lainnya yang berupa pemukiman, kebun, dan ladang ladang. Sebagai fokus pengamatan dengan memetakan wilayah pemukiman yang berpotensi terdampak dengan jaringan pipa minyak dan gas. Penggunaan Lahan Kecamatan Kedokanbunder dapat dilihat pada Gambar 3.

\section{Analisis Letak Pipa Minyak dan Gas di Kecamatan Kedokanbunder.}

Kecamatan Kedokanbunder terdiri dari tujuh desa, yaitu Desa Jayalaksana, Desa Cangkingan, Desa Jayawinangun, Desa Kedokanbunder, Desa Kedokan Agung, Desa Kedokan Wetan, dan Desa Kaplongan. Dari ketujuh desa tersebut, tidak semua desa dilewati oleh pipa minyak dan gas. Desa yang dilalui oleh jalur pipa minyak dan gas tersebut yaitu Jayawinangun, Kedokanbunder, Kedokan Agung, dan sebagian Desa Kedokan Wetan.

Penggunanaan lahan yang dilewati oleh jalur pipa minyak dan gas tersebut juga tidak semuanya berupa pemukiman, tetapi juga pada penggunaan lahan pertanian seperti sawah sehingga yang terdampak tidak hanya wilayah permukiman. Untuk letak sebaran jaringan pipa minyak dan gas di Kecamatan Kedokanbunder disajikan pada Gambar 4.

\section{Analisis Ledakan Pipa Minyak dan Gas terhadap Penggunaan Lahan di Kecamatan Kedokanbunder}

Dalam penelitian ini, radius yang digunakan untuk menentukan tingkat ledakan yaitu 100 meter, 300 meter, dan 500 meter dari keberadaan pipa minyak dan gas. Masing-masing dari radius tersebut memiliki tingkat kerusakan atau terdampak yang dapat dilihat pada Tabel 1: 
Tabel 1. Tingkat Potensi Kerusakan Berdasarkan Jarak Terhadap Pipa Minyak dan Gas.

\begin{tabular}{|c|c|c|}
\hline No. & Radius (m) & Tingkat Kerusakan \\
\hline 1 & 100 & Berat \\
\hline 2 & 300 & Sedang \\
\hline 3 & 500 & Rendah \\
\hline
\end{tabular}

Tingkat kerusakan akibat ledakan dipengaruhi oleh kondisi meteorologis, jenis zat kimia, volume uap bahan kimia, sifta dari bahan kimia, laju penguapan zat kimia, serta geometri wilayah berupa jarak dan halangannya (Lestari, 2016). Hal ini tentu bukan ranah bagi seorang geograf untuk menghitungnya sehingga penentuan jarak dan tingkat kerusakan tersebut hanya didasarkan pada kemungkinan dan perkiraan peneliti. Pemodelan potensi ledakan berdasarkan radius terpaparnya obyek pada area peruntukan lahan dapat dilihat pada Gambar 5.

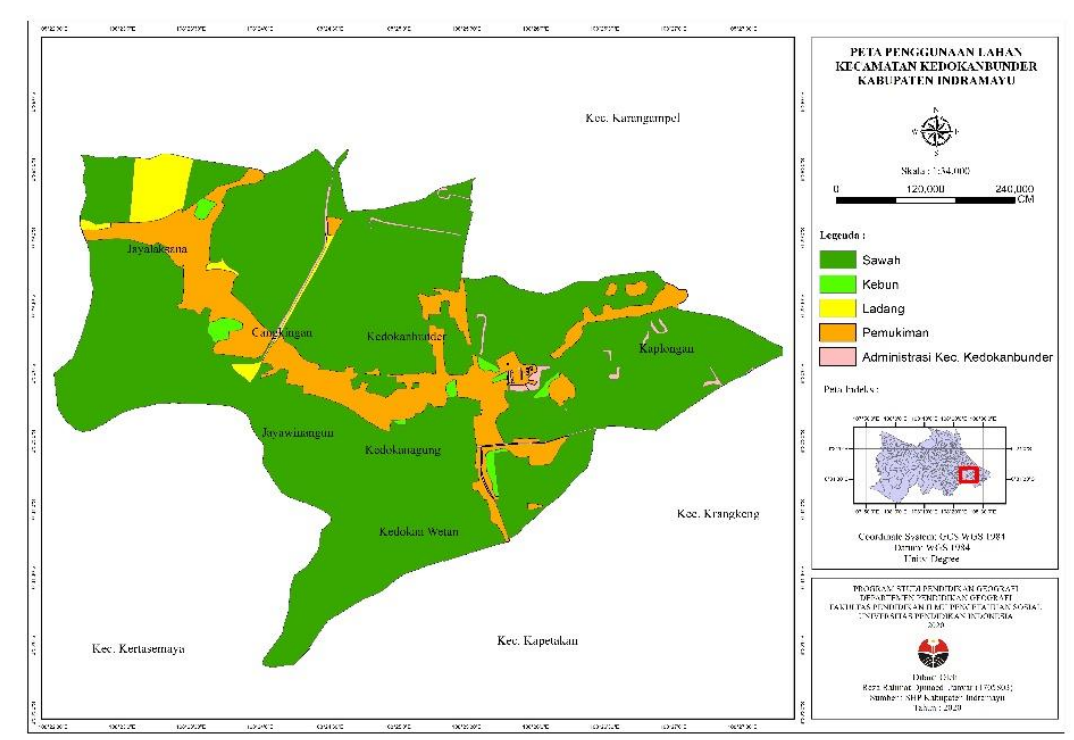

Gambar 3. Penggunaan Lahan Kecamatan Kedokanbunder

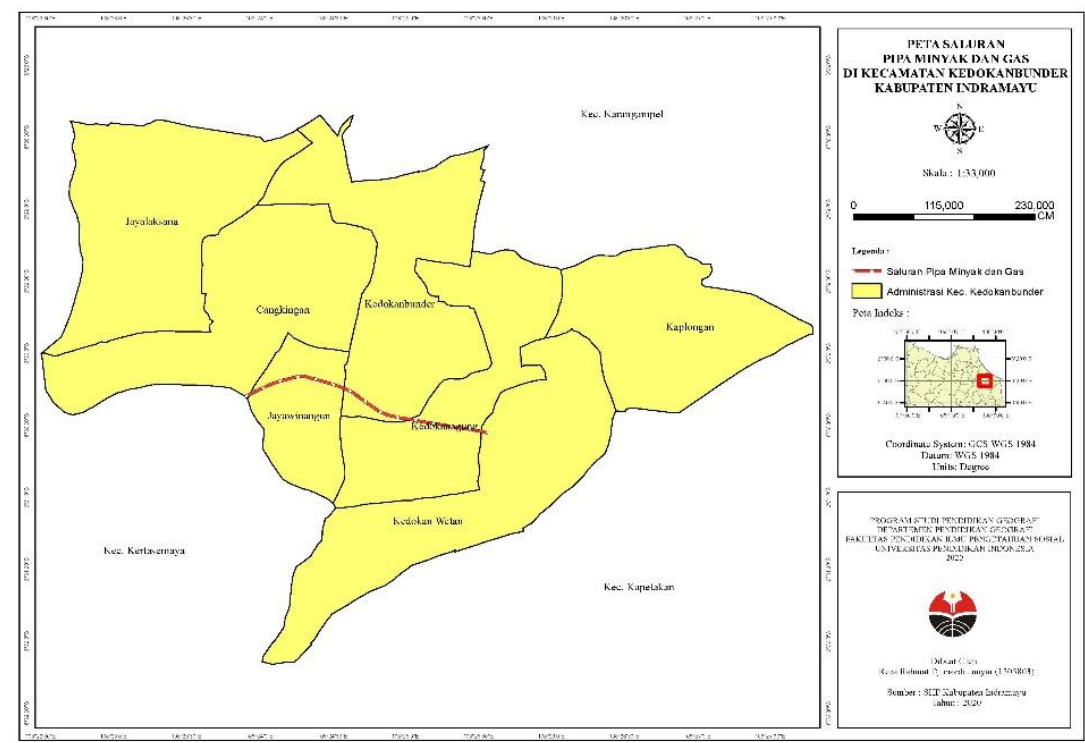

Gambar 4. Lokasi Jalur Pipa Gas 


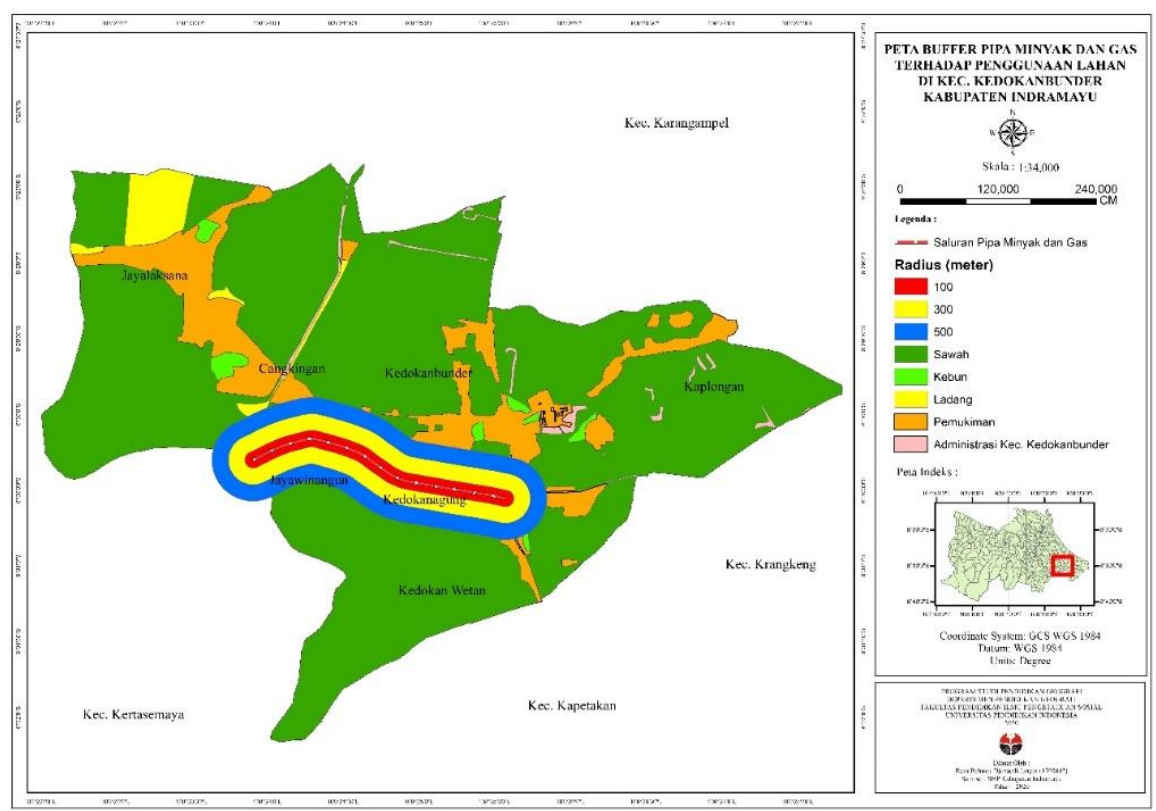

Gambar 4. Buffer jaringan Pipa Minyak dan Gas Terhadap Penggunaan Lahan

Berdasarkan peta Gambar 5, maka dampak yang dihasilkan dari ledakan pipa minyak dan gas terhadap penggunaan lahan di Kecamatan Kedokanbunder dapat diuraikan pada tabel 2:

Tabel 2 Penggunaan Lahan Terdampak Ledakan Pipa Minyak dan Gas

\begin{tabular}{|c|c|}
\hline No. & $\begin{array}{c}\text { Penggunaan Lahan } \\
\text { Terdampak }\end{array}$ \\
\hline 1 & Permukiman \\
\hline 2 & Sawah \\
\hline 3 & Ladang \\
\hline 4 & Kebun \\
\hline
\end{tabular}

Analisis Pemukiman Terdampak dan Zonasi Potensi Ledakan Pipa Minyak dan Gas.

Dari tujuh desa yang terdapat di Kecamatan Kedokanbunder, hanya terdapat empat desa yang dilalui oleh jalur pipa minyak dan gas. Desa tersebut yaitu Jayawinangun, Kedokanbunder, Kedokan Agung, dan Kedokan Wetan. Berdasarkan situasi lokasi obyek bahwa kategori tingkatan zona yang digunakan yaitu 100 meter, 300 meter, dan 500 meter dari lokasi letak jaringan pipa minyak dan gas. Dari lokasi dan jarak obyek elemen berisiko pemukiman terdapat tiga kelas zona. Zona yang dimaksud yaitu zona merah yang artinya kemungkinan terdampak berat dengan radius 100 meter, zona kuning yang artinya kemungkinan terdampak sedang dengan radius 300 meter, dan zona hijau yang artinya kemungkinan terdampak rendah dengan radius 500 meter dari letak pipa minyak dan gas. Zonasi potensi wilayah terdampak disajikan dalam peta zonasi potensi pemukiman terdampak (Gambar $6)$.

Hasil analisis metode Buffer berdasarkan peta Gambar 6, menunjukkan bahwa mayoritas pemukiman di wilayah penelitian berada di zona hijau yaitu pada radius 500 meter. Selain itu, terdapat area pemukiman wilayah penelitian berada pada zona kuning dan zona merah. Wilayah dengan zona merah merupakan wilayah yang dekat atau dilalui oleh jalur pipa gas dengan radius 0-100 meter.

Distribusi wilayah penelitian yang teridentifikasi pada zona merah, kuning, dan hijau disajikan pada Tabel 3. Pada 
zona merah terdapat 4 desa, zona kuning terdapat 5 desa, dan zona hijau terdapat 5 desa. Informasi hasil pemetaan zonasi potensi risiko terhadap bencana ledakan sebagai dasar informasi untuk mitigasi bencana secara structural atau non structural (Dahlia et al., 2019).

Tabel 3. Zonasi Pemukiman Terdampak Ledakan Pipa Minyak dan Gas

\begin{tabular}{|c|c|l|}
\hline No. & Zona & \multicolumn{1}{c|}{ Wilayah } \\
\hline 1 & Merah & $\begin{array}{l}\text { Jayawinangun, } \\
\text { Kedokan Agung, } \\
\text { Kedokanbunder, dan } \\
\text { Kedokan Wetan }\end{array}$ \\
\hline 2 & Kuning & $\begin{array}{l}\text { Jayawinangun, } \\
\text { Cangkingan, Kedokan } \\
\text { agung, Kedokan } \\
\text { bunder, dan Kedokan } \\
\text { Wetan. }\end{array}$ \\
\hline
\end{tabular}

\begin{tabular}{|c|l|l|}
\hline 3 & Hijau & $\begin{array}{l}\text { Jayawinangun, } \\
\text { Cangkingan, Kedokan } \\
\text { agung, Kedokan } \\
\text { bunder, dan Kedokan } \\
\text { Wetan. }\end{array}$ \\
\hline
\end{tabular}

\section{KESIMPULAN}

Pemukiman zona merah dengan radius 100 meter dari pipa minyak dan gas berada pada desa Jayawinangun, Kedokan Agung, Kedokanbunder, dan Kedokan Wetan. Pemukiman zona kuning yaitu dengan radius 300 meter dari pipa minyak dan gas terdapat pada desa Jayawinangun, Cangkingan, Kedokan agung, Kedokan bunder, dan Kedokan Wetan. Sementara pemukiman zona hijau atau radius 500 meter dari pipa minyak dan gas terdapat pada desa Jayawinangun, Cangkingan, Kedokanagung, Kedokan bunder, dan Kedokan Wetan.

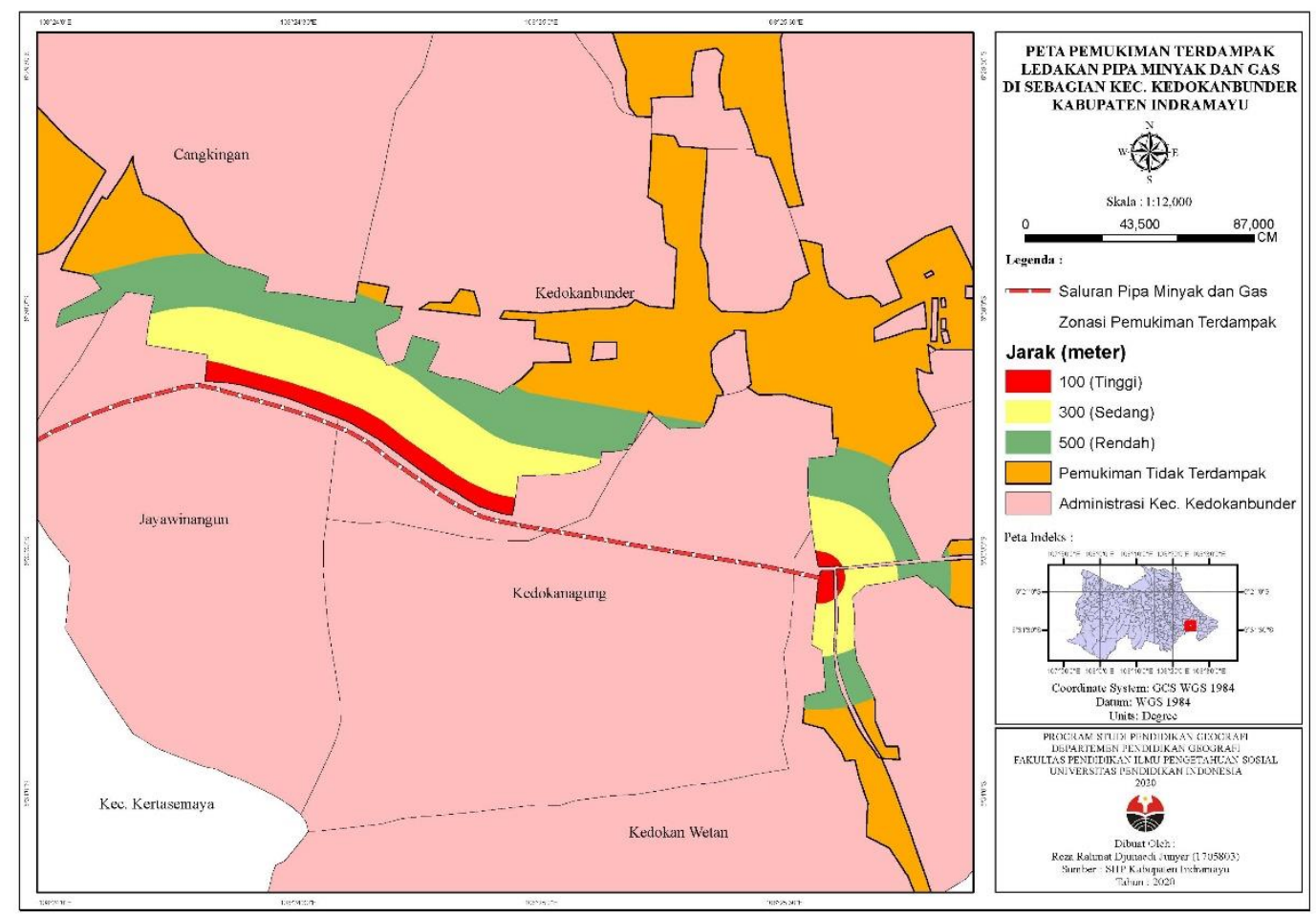

Gambar 6. Peta Pemukiman Terdampak Ledakan Pipa Minyak dan Gas di Sebagian Kecamatan Kedokanbunder 


\section{DAFTAR PUSTAKA}

Adil, A. (2016). Analisa Spasial Pemetaan Lokasi Wisata Agro. Jurnal Matrik, 16(1), 1-11.

Andreva, V. (2010). Studi Ketersediaan Lokasi Perumahan Kawasan Perkotaan Sragen Tahun 2028. Diambil kembali dari Digilib UNS web site:

http://www.digilib.uns.ac.id

Aqli, W. (2010, Desember). Analisa Buffer dalam Sistem Informasi Geografis untuk Perencanaan Ruang Kawasan. Jurnal Teknik Sipil dan Arsitektur, VI(2), 192201.

Dahlia, S., Rosyidin, W. F., \& Nurbudiansah, A. D. (2017). Partisipasi Masyarakat Dalam Pemetaan Bahaya Banjir Menggunakan Pendekatan Multi Disiplin di Desa Renged Kecamatan Binuang Kabupaten Serang. Jurnal Geografi Edukasi dan Lingkungan, I(1), 48-56.

Dahlia, S., Rosyidin, W. F., Ramadhan, A., Haryadi, Anwar, K., Ersantyo, D., ... Zahroh, A. A. (2019). Pemetaan Kerawanan Kebakaran Menggunakan Pendekatan Integrasi Penginderaan Jauh Dan Persepsi Masyarakat Di Kecamatan Tambora Jakarta Barat. Jurnal Geografi, 11(1), 108-123.

Irwansyah, E. (2013). Sistem Informasi Geografis : Prinsip Dasar dan Pengembangan Aplikasi. Yogyakarta: Digibooks.

Pradana, R. K., \& Dwiyanti, E. (2013). Hydrogen Recovery Unit (HRU) dan Prioritas Risiko Kegagalan Komponen Pipa Gas Hidrogen di $\mathrm{PT}$ Petrokimia. The Indonesian Journal of Occupational Safety and Health, I(1), 10-19.
Rosyidin, W. F., Sribrotopuspito, K., Sunarto, Pambudi, P., Dahlia, S., \& Wisesa, A. (2016). Kajian Dampak Bahaya Kegagalan Teknologi PLTU-PLTGU Terhadap elemen Berisiko di UP Muara Karang. Geo Edukasi.

Syamsir, \& Daramussseng, A. (2018). Analisis spasial efektivitas fogging di wilayah kerja puskesmas markoman, kota samarinda. Jurnal Nasional Ilmu Kesehatan (JNIK), 1, $1-7$.

Utami, T. S., \& Sedjati, S. (2014). Studi Penggunaan Kitosan Terhadap Penurunan Kadar Amoniak Pada Limbah Cair Kilang Minyak OIB Pertaminan RU VI Balongan Indramayu. Journal of Marine Research, III(1), 20-26.

Wijaya, A. P., Wahyutomo, P. K., \& Suprayogi, A. (2016). Aplikasi Sistem Informasi Geografis Berbasis Web untuk Persebaran Kantor POS di Kota Semarang dengan Google Maps API. Jurnal Geodesi Undip, 70-80. 